\author{
生体硬組織のエキシマレーザー蒸散機構 \\ 中野 人志, 中山 斌義, 久保 宇市 \\ 近畿大学理工学部電気工学科（广 577-0818 大阪府東大阪市小若江 3-4-1）
}

\title{
Mechanism Associated with Excimer Laser Ablation of Hard-Tissue
}

\author{
Hitoshi NAKANO, Takeyoshi NAKAYAMA, and Uichi KUBO \\ Department of Electrical Engineering, Faculty of Science and Technology, KINKI University \\ 3-4-1 Kowakae, Higashiosaka, Osaka 577-0818
}

(Received October 2, 1997)

\begin{abstract}
The mechanism associated with excimer laser ablation of hard tissue has been studied using fast photography and an electron probe micro analyzer (EPMA). A bovine femur was adopted as a model of hard tissue. The $\mathrm{ArF}$ and $\mathrm{KrF}$ excimer lasers were used in this study. Time-resolved photographs of ablation plume were obtained using a microscope-mounted camera together with pulsed illumination from a $\mathrm{XeCl}$ excimer laser pumped dye solution. Ablation velocity and the start time of ablation were estimated. In addition, change in composition of bone surface was investigated by EPMA. The ratio of Calcium to Phosphor, which is an important parameter for determining the chemical characteristics of Hydroxyapatite, was estimated. Possible mechanisms to explain laser ablation were examined. The results indicated that the $\mathrm{ArF}$ and $\mathrm{KrF}$ excimer lasers promoted primarily photothermal ablation. Photochemical ablation had occurred only in ArF excimer laser irradiation. Photomechanical ablation appeared to be negligible during $\mathrm{ArF}$ and $\mathrm{KrF}$ excimer laser ablation of bone.
\end{abstract}

Key Words: $\quad$ Excimer laser ablation, Bone, Fast photography, EPMA

1.はじめに

医療用のレーザーとしては, 眼科領域のArレーザー, 凝 固治療のNd:YAGレーザー,切開治療のCO 2 レーザー等がよ く知られている。 今日では, その他臨床現場の幅広い領域 でレーザーが使用されており,有用性が認められている。 紫外領域でパルス発振するエキシマレーザーは, 従来まで の $\mathrm{CO}_{2}$ レーザーに見られる生体組織断端部の熱損傷, 炭化 等を極力抑え込むことができる ${ }^{1,2)}$. 眼科における角膜屈 折矯正手術には, 既に $\mathrm{ArF}$ エキシマレーザーが使用されて おり3)，他の領域においてもエキシマレーザーを応用する 研究が行われている。しかしながら,核酸の吸収ピーク波 長が紫外領域に存在することから, エキシマレーザーの生 体軟組織への照射には安全性の確保が必要であり,限界が ある。

骨や歯牙等の生体硬組織においては, エキシマレーザー を用いた研究が多岐に亘って行われている4-17). エキシマ レーザーの硬組織蒸散機構については種々の要因が考え られ, 現在においても完全な解答は見いだせないが, 光化 学効果の寄与が考えられている ${ }^{13,18)} . \mathrm{KrF}$ (波長：248nm) や $\mathrm{ArF}$ (波長：193nm) エキシマレーザーが発する紫外光の

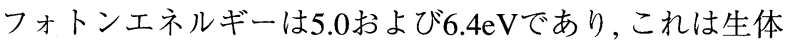
に含まれる様々な分子の結合エネルギーを上回るか同程 度かである。
一方, 生体構成物質は, 通常, 有機成分を多く含み紫外領 域において大きな吸収を持っている。これは,熱による蒸 散の機構がフォトンエネルギーの大小に関わらず大きい ことを意味している。エキシマレーザーによる生体硬組 織の蒸散機構については, 高速イメージングを用い, 既に 多数の報告がなされている6,10,11,14-16). 噴出粒子の速度, 衝 撃波の発生状況, プラズマ発光の分光分析等, 詳細に報告 されているが,レーザー照射直後における蒸散の状況や光 化学効果に着目した検討は行われていない.

本研究では, $\mathrm{ArF}$ および $\mathrm{KrF}$ のキシマレーザーを生体硬 組織に照射し, 形成されたプルームの時間分解写真測定結 果から, 蒸散の機構を熱的, 機械的, 光化学的効果の3つに 分けて検討した.さらに, 照射表面を電子線プローブマイ クロアナライザー (EPMA)を用いて観測し, 光化学効果に よる原子組成変化の有無を調べた。

\section{2. 生体硬組織試料および実験方法}

実験に用いたレーザーは, ArF (Lambda Physik, LPX 105 MSC)およびKrF(Lambda Physik, EMC 103 MSC)のエキシ マレーザーである。レーザー発振波長とパルス幅は, ArF の場合193nm, 15ns, KrFは248nm, 23nsである．生体硬組織 試料としては牛大腿骨を用いた。骨は主として有機成分 と無機成分から構成され, 有機成分は主にコラーゲン, 無 


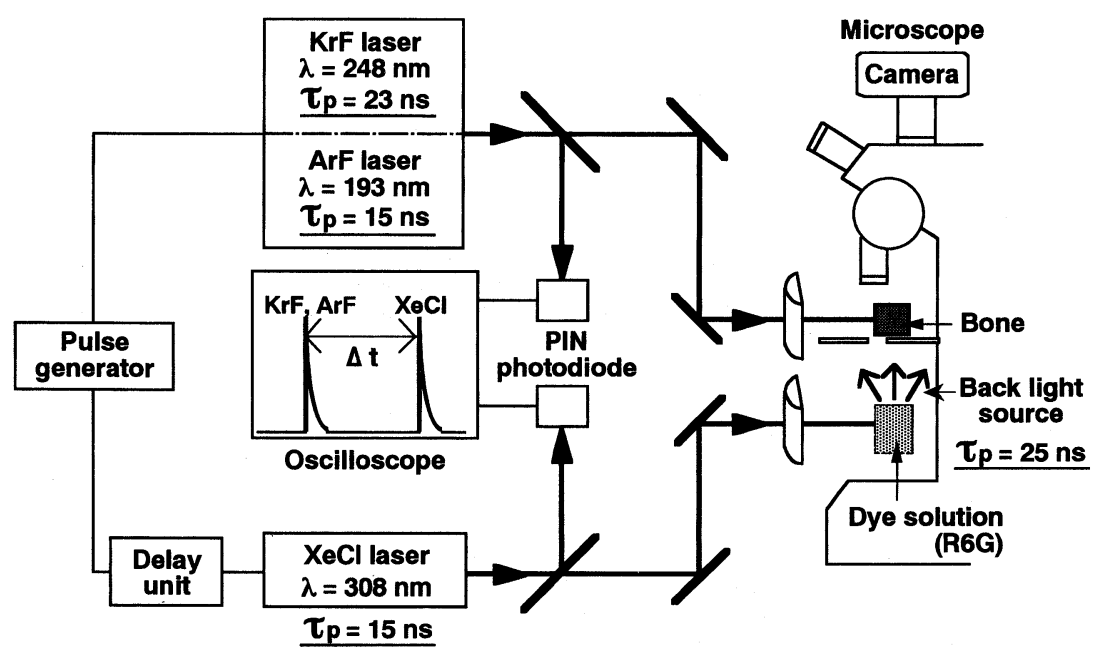

Fig.1 Experimental arrangement for measuring time-resolved image of excimer laser ablation plume.

機成分はハイドロキシアパタイト $\left(\mathrm{Ca}_{10}\left(\mathrm{PO}_{4}\right)_{6}(\mathrm{OH})_{2}\right.$, 以下 HAp)である19). HApは通常多結晶の状態で存在してい る。骨表層部分の皮質骨における有機成分と無機成分は 各々 $35 \%, 50 \%$ あり,残りの $15 \%$ は水分である ${ }^{19)}$. 本実験 では, 皮質骨を使用した。レーザー波長に対する骨の吸収 は, 懸濁液を使った分光測定から, ArF波長の方が26倍大き いことが判っている20).

蒸散の機構を検討するために, プルームの時間分解写真 測定を行った。実験配置をFig.1に示す．照射レーザー光 と同期発光するナノ秒可視光をバックライト光源として 利用するのが, 時間分解写真測定の原理である ${ }^{21)} . \mathrm{ArF}$ あ るいはKrFエキシマレーザー光をシリンドリカルレンズで 線集光し,フルエンスを $1 \mathrm{~J} / \mathrm{cm}^{2} \cdot \mathrm{pulse}$ 一定として牛大腿骨に

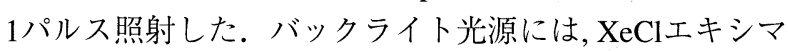
レーザー(日本電気, XL120A, 波長308nm, パルス幅 $15 \mathrm{~ns}$ ) 励 起された色素溶液(ローダミン6G) からの蛍光を用いた。 バックライト光の中心波長とパルス幅は, それぞれ $590 \mathrm{~nm}$, 19nsであった. プルーム発生の時間履歴を広範囲で測定す るために, デジタル遅延パルサー (Stanford Research Inc., DG535)を用い, 照射エキシマレーザー光とバックライト光 の時間間隔 (以下, 遅延時間)を変化させた. エキシマレー ザー同期発振におけるジッターの影響を考慮するため, 遅 延時間は照射レーザーパルスとXeClレーザーパルスをPIN ホトダイオードで測定して直接評価した。 また, 遅延時間 は各レーザーパルスのピーク間隔で定義し, 同軸ケーブル 長, 試料までの光路長は別途評価した。

レーザー照射表面の原子組成分析には, EPMA（日本電 子, JXA-8600S/M)を用いた。この実験では, ArFおよびKrF エキシマレーザー光を繰り返し周波数2ppsで 1000 パルス骨 に照射した，原子組成変化の指標として, HApの化学的性 質の決定において重要な $\mathrm{Ca}$ と $\mathrm{P}$ の原子組成比 (以下, $\mathrm{Ca} / \mathrm{P}$ ) を評価した。

\section{3. 実験結果}

\section{1 時間分解写真測定}

Fig.2 (a)，(b)にプルームの時間分解写真を示す. (a)は
$\mathrm{ArF} （ \mathrm{~b})$ がKrFエキシマレーザー照射の結果である. 図で は上方からレーザーが照射されている。(a), (b)図ともに, 遅延時間25nsにおいて骨の表面に変化が現れている。 その

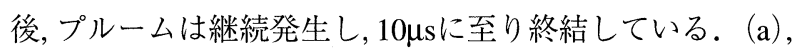
(b)図ともに遅延時間400nsにおいて最も顕著に観られるプ ルーム上方の円状縞は衝撃波の波紋であり, プルームが超 音速で噴き出していることが判る. 衝撃波の可視化は, 空 気の密度変化によって生じる屈折率変化に起因する。飛 散した粒子の径は, 概ね $2 \mu \mathrm{m}$ 以下であり, 僅かであるが $10 \mu \mathrm{m}$ 程度, あるいはそれ以上のものもあった。

Fig.3 (a), (b)には,プルームの噴出距離と遅延時間の関 係を示している。ここで噴出距離は骨表面からの最大噴 出距離で定義した。（b)図は (a)図での遅延時間の短い領域 を拡大して示したものである. 図中に示した実線は, 噴出 粒子の振舞いがストークス則に従うと仮定した指数関数 によるフィッティング曲線である。フィッティング結果 から,レーザー照射から蒸散が開始するまでの時間 $\left(t_{\mathrm{s}}\right)$ と初 速度 $\left(V_{0}\right)$ を求めると, $\mathrm{ArF}$ エキシマレーザー照射において は, $t_{\mathrm{s}}=0 \mathrm{~ns}, V_{0}=1.5 \times 10^{3} \mathrm{~m} / \mathrm{s}, \mathrm{KrF}$ キシマレーザーでは, $t_{\mathrm{s}}$ $=17 \mathrm{~ns}, V_{0}=2.7 \times 10^{3} \mathrm{~m} / \mathrm{s}$ となった. $\mathrm{ArF}, \mathrm{KrF}$ エキシマレー ザーにおいて得られたこれらの結果は, 単純に吸収の違い からは説明できないものとなった. ArFエキシマレーザー では照射直後に蒸散が開始していることになり, Fig.2 (a) の遅延時間0nsでプルームあるいはデブリスが確認出来な

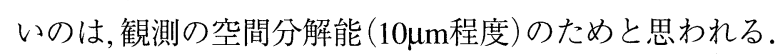

\section{2 原子組成变化の測定}

原子組成変化を調べるために, EPMAを用いてレーザー 照射面における骨のCa/Pを評価した．結果を照射フルエン スの関数としてFig.4に示す，骨の試料には個体差がある ために未照射の場合でも原子組成比に変化が見られる. そのため, Fig.4の縦軸においては, レーザー照射後のCa/P 比を同一試料における未照射部でのCa/Pで割った值 $((\mathrm{Ca} /$ $\left.\mathrm{P}) /(\mathrm{Ca} / \mathrm{P})_{0}\right)$ を採用した. すなわち, 図中の 1 が原子組成比 の無変化を表していることになる．KrFエキシマレーザー 照射では原子組成比に大きな変化は観られないが, $\mathrm{ArF} 工$ キシマレーザー照射では低エネルギーフルエンス $(0.5$ 


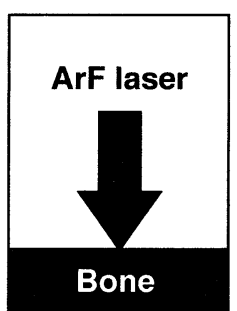

Delay time

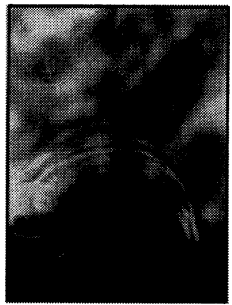

200 ns

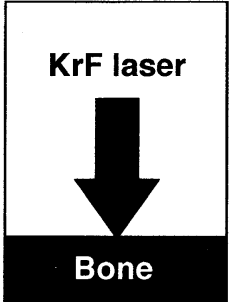

Delay time

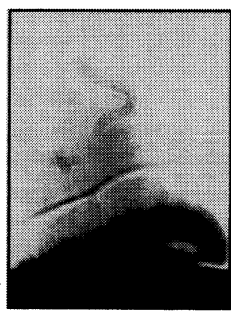

200 ns

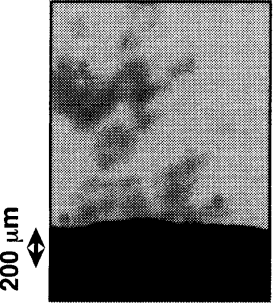

O ns

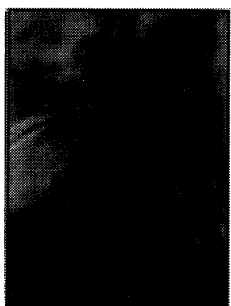

400 ns

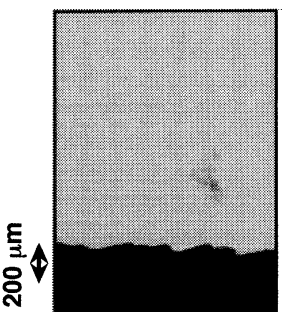

O ns

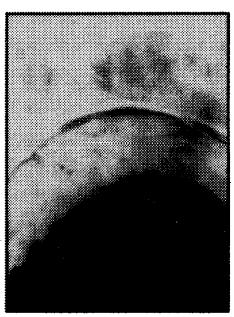

400 ns

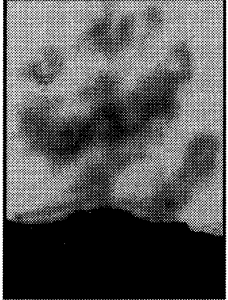

$25 \mathrm{~ns}$

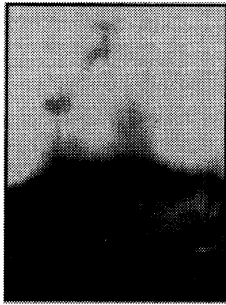

$1 \mu s$

(a)

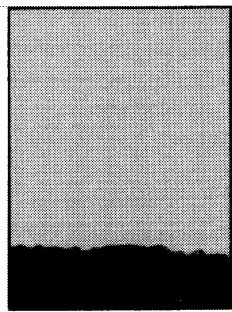

$25 \mathrm{~ns}$

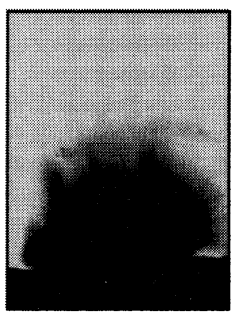

$1 \mu s$

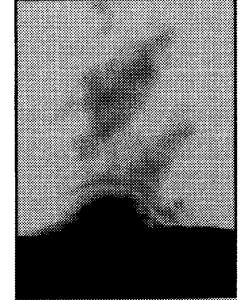

80 ns

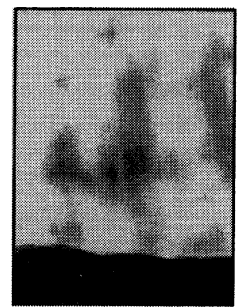

$10 \mu s$

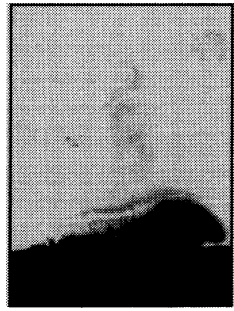

85 ns

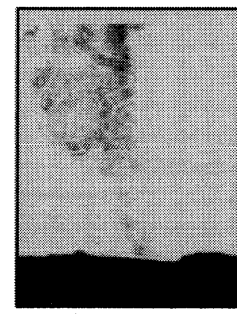

$10 \mu s$

(b)

Fig.2 Fast photographs of excimer laser ablation of bone. (a) ArF excimer laser ablation and (b) KrF excimer laser ablation.

$\mathrm{J} / \mathrm{cm}^{2} \cdot \mathrm{pulse}$ 以下) において大きく変化していることが判 る. $\mathrm{Ca} / \mathrm{P}$ の増加はP $\mathrm{P}$ 原子が相対的に減少したことを示唆す る。一方, 高エネルギーフルエンスでは, 原子組成比の変 化は観られなかった。

\section{4. 検討および考察}

エキシマレーザーの蒸散機構は, 熱的, 機械的 (剥離, 破 壊), 光化学的機構の3つに分けて考えることができ る22,23). 熱効果による蒸散は,物質内部におけるレーザー エネルギーから熱エネルギーへの変換とその熱の拡散に 起因する。レーザー吸収層から電子熱伝導で蒸散層まで エネルギーが運ばれる。実験では $\mathrm{ArF}, \mathrm{KrF}$ エキシマレー ザーともにマイクロ秒まで継続してプルームが噴出し た。両レーザー共にパルス幅はナノ秒オーダであり,熱効 果による蒸散の機構が支配的であると考えられる.

物質の破断応力が小さい場合に, 急激な温度上昇で発生
する膨張波が物質を機械的に剥離，破壊する機構があ る22). 前述のように, 本実験で用いたフルエンスではプ ルームの径は概ね $2 \mu \mathrm{m}$ 以下と小さく, $\mathrm{ArF}, \mathrm{KrF}$ エキシマレー ザーで骨切開を行った場合に断端部に生ずる針状の構造 は $5 \mu \mathrm{m}$ 以下であり ${ }^{24)}$, 機械的な蒸散機構の寄与は小さいと 考えられる。

光化学的な蒸散は, 直接あるいは前期解離による分子結 合の切断に起因する. 結合の切断に要する時間はサブピ コ秒程度であるため, 蒸散はレーザー照射直後から開始す ると考えられる。対象とする骨の吸収が異なるため単純

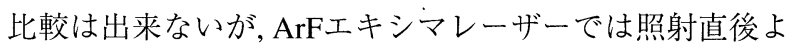
り蒸散が開始しており, 光化学的な機構を考えることが出 来る．一方, $\mathrm{KrF}$ エキシマレーザーでは, 照射レーザーパル ス終了後に蒸散が始まるため光化学効果の寄与はArFエキ シマレーザーに比べて小さいと考えられる. Fig.4に示し たEPMAによる原子組成变化の測定結果は, 上記の検討と 矛盾しないものである. 光化学効果による結合の切断は1 


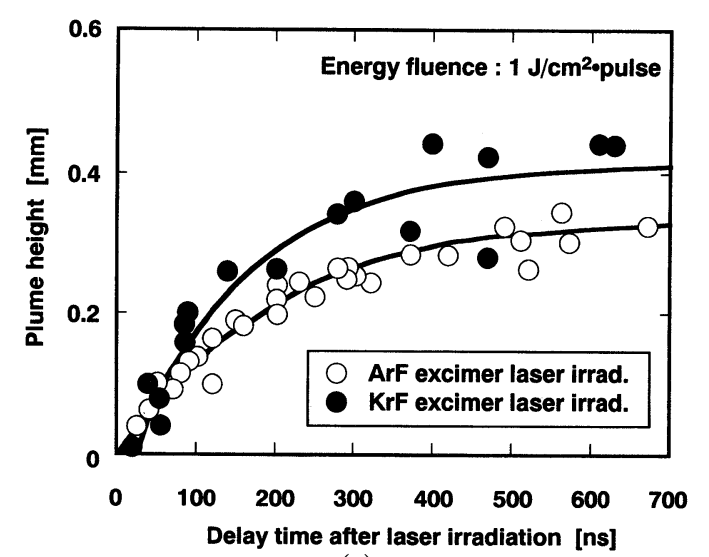

(a)

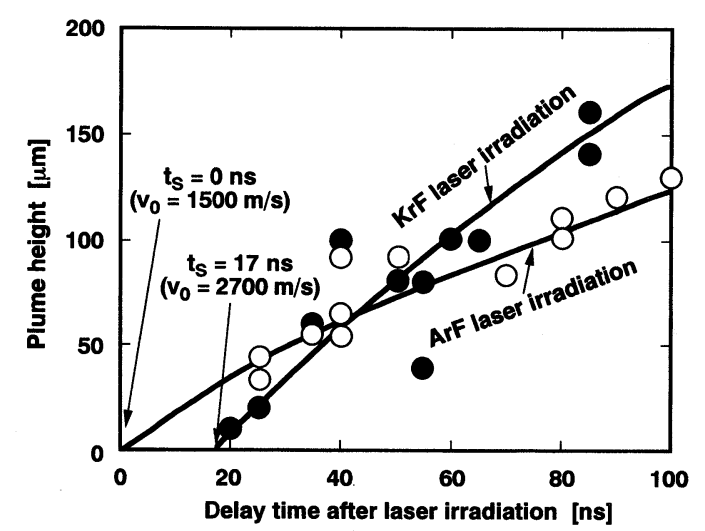

(b)

Fig.3 Relationship between plume height and delay time after laser irradiation. (a) Whole delay time region and (b) Short delay time region.

フォトンの吸収によるものの他, 照射フルエンスの大きさ によって2フォトンあるいはマルチフォトン吸収で生じ る25). HAp中の結合エネルギーには, 低いものから順に $\mathrm{P}-\mathrm{O}$ (結合エネルギー: $3.7 \mathrm{eV}), \mathrm{Ca}-\mathrm{O}(4.8 \mathrm{eV}), \mathrm{P}=\mathrm{O}(5.7 \mathrm{eV})$, $\mathrm{Ca}-\mathrm{O}(11 \mathrm{eV})$ がある26). ArFおよび $\mathrm{KrF}$ エキシマレーザーの フォトンエネルギーはそれぞれ6.4, 5.0eVであり, $\mathrm{ArF}$ 1 フォトン吸収ではP-O, $\mathrm{Ca}-\mathrm{O}, \mathrm{P}=\mathrm{O}$ の切断が可能となる。 こ れはP原子の結合が放出され, $\mathrm{P}$ 原子が相対的に減少する結 果を導く. 低フルエンス領域における $\mathrm{Ca} / \mathrm{P}$ 比の増加は, 1 フォトン吸収によるP原子の選択的な放出を定性的に説明 できる結果である。フルエンスの増加によって $\mathrm{Ca} / \mathrm{P}$ 比が1 に漸近するのは, 現象が2あるいはマルチフォトン吸収過程 に推移したことを示唆する.2フォトン吸収ではCa-Oを含 む全ての結合の切断が可能であり, 原子放出の選択性は消 滅する， KrFエキシマレーザー照射では全フルエンス領域 を通じて, 原子組成比変化は生じておらず, 光化学効果の 寄与が小さいとした前述の結論と矛盾しない.

\section{5. まとめ}

牛大腿骨に $\mathrm{ArF}, \mathrm{KrF}$ エキシマレーザーを照射し, 蒸散の 機構をプルームの時間分解測定および骨表面のEPMA分析 によって調べた。主な蒸散の機構は, 両レーザーともに, 熱 の効果であることが判った，但し, $\mathrm{ArF}$ エキシマレーザー の場合には照射直後より蒸散が開始し, 表面に原子組成変

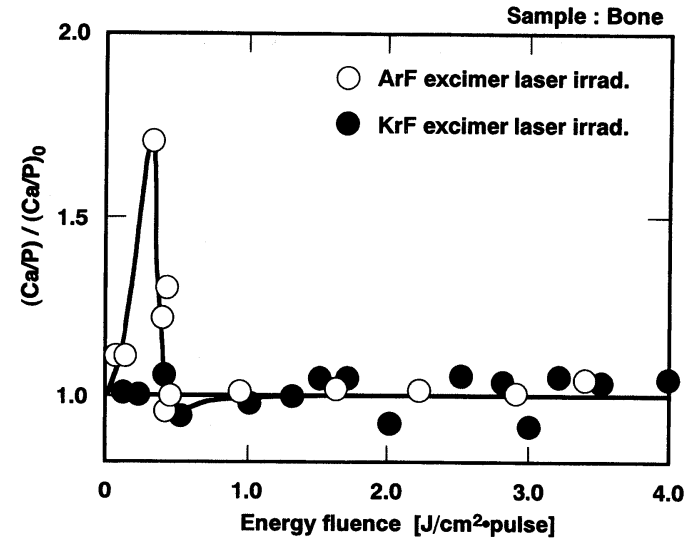

Fig.4 The ratio of Ca to P estimated by EPMA, as a function of energy fluence.

化が現れるので, 光化学効果の寄与も考えられる.レー ザー照射によって衝撃波が発生したが, 本実験で用いたフ ルエンスでは, 骨の機械的な破壊には至らないことが判っ た。

\section{参考文献}

1）久保 宇市：日本レーザー医学会誌 9 (1988) 403.

2) R. Srinivasan: Science 234 (1986) 559.

3) S. Trokel, R. Srinivasan, and B. Braren: Am. J. Ophthalmol 96 (1983) 710.

4) J. S. Nelson, A. Orenstein, L. H. Liaw, R. B. Zavar, S. Gianchandani, and M. W. Berns: Appl. Optics 28 (1989) 2350.

5) R. Sarkar, R. L. Fabian, R. C. Nuss, and C. A. Puliafito: Am. J. Otolaryngol. 10 (1989) 76.

6) J. Neev, L. L. Liaw, D. V. Raney, J. T. Fijishige, P. D. Ho, and M. W. Berns: Laser Surg. Med. 9 (1989) 499.

7) J. A. Izatt, N. D. Sankey, F. Partovi, M. Fitzmaurice, R. P. Rava, I. Itzkan, and M. S. Feld: IEEE J. Quantum Electron. 26 (1990) 2261.

8) M. Dressel: Laser Surg. Med. 11 (1991) 569.

9) A. Yablon: Laser Surg. Med. 11 (1991) 238.

10) J. Lustman, M. Ulmansky, A. Fluxbrunner, and A. Lewis: Lasers Surg. Med. 11 (1991) 51.

11) J. Neev, D. V. Raney, W. E. Whalen, J. T. Fujishige, P. D. Ho, J. V. Mcgrann, and M. W. Berns: Lasers in the Life Science 5 (1992) 129.

12) 岡田和之, 岸田克彦, 久保 宇市: 第11回日本レーザー医学会 大会論文集 (1990) p.621.

13）中山斌義, 久保 宇市：レーザー研究 20 (1992) 845.

14) 藤阪 紳一, 伊藤利昭, 佐藤勝彦：レーザー研究 22 (1994) 402.

$15)$ 藤阪紳一, 伊藤 利昭, 佐藤勝彦：レーザー研究 22 (1994) 552.

16）佐藤勝彦, 垣内岳春, 鈴木 孝：レーザー研究 22 (1994) 559.

17) 佐藤 勝彦, 藤阪 紳一: 電学論 C 114 (1994) 529.

18) N. P. Furzikov: IEEE J. Quantum Electron. QE-23 (1987) 1751.

19) 須田立雄, 小澤栄治, 高橋 英明: 骨の化学 (医歯薬出版, 1987) p.111.

20) 土井 建治, 下山 義夫, 原口 能純, 中山 斌義, 久保 宇市 : 近畿 大学理工学部研究報告 29 (1993) 127.

21) C. A. Piliafito, D. Stern, R. R. Kruegen, and E. R. Mandel: Arch. Ophthamol. 105 (1987) 1255.

22) S. L. Jacques, Surg.: Clin. North Am. 72 (1992) 531.

23) A. J. Welch and M. J. C. Van Gemert: Optical-Thermal Response of Laser-Irradiated Tissue (Plenum Press, New York and London, 1995) Chap. 21.

24）中山斌義, 久保 宇市：レーザー学会研究会報告 RTM-94-21 (1994) 39.

25) R. Srinivasan, B. Braren, and R. W. Dreyfus: J. Appl. Phys. 61 (1987) 372.

26) R. T. Sanderson ; 坪井 正道, 武貞 啓子訳 : 化学結合と結合工 ネルギー(講談社サイエンティフィック, 1979) p.115. 